\title{
Developing Evidence-based Population Health Informatics curriculum: Integrating competency based model and job analysis
}

\author{
Ashish Joshi PhD, MBBS, MPH ${ }^{1 *}$, Irene Bruce, $\mathrm{MPH}^{2}$, Chioma Amadi, $\mathrm{PhD}^{3}$, Jaya Amatya, $\mathrm{MPH}^{4}$, \\ ${ }^{1}$ CUNY Graduate School of Public Health and Health Policy, NY \\ ${ }^{2}$ CUNY Graduate School of Public Health and Health Policy, NY \\ ${ }^{3}$ Adjunct Faculty, CUNY Graduate School of Public Health and Health Policy, NY \\ ${ }^{4}$ Montefiore Medical Center, NY
}

\begin{abstract}
With the rapid pace of technological advancements, public health professions require a core set of informatics skills. The objective of the study is to integrate informatics competencies and job analysis to guide development of an evidence-based curriculum framework and apply it towards creation of a population health informatics program. We conducted content analysis of the Population Health Informatics related job postings in the state of New York between June and July 2019 using the Indeed job board. The search terms included "health informatics" and "population health informatics." The initial search yielded 496 job postings. After removal of duplicates, inactive postings and that did not include details of the positions' responsibilities resulted in 306 jobs. Information recorded from the publicly available job postings included job categories, type of hiring organization, educational degree preferred and required, work experience preferred and required, salary information, job type, job location, associated knowledge, skills and expertise and software skills. Most common job title was that of an analyst $(21 \%, n=65)$ while more than one-third of the hiring organizations were health systems $(35 \%, n=106) .95 \%(n=291)$ of the jobs were fulltime and nearly half of these jobs were in New York City $(47 \%, n=143)$. Data/statistical analysis $(68 \%, n=207)$, working in multidisciplinary teams $(35 \%, n=108)$, and biomedical/clinical experience $(30 \%, n=93)$ were the common skills needed. Structured query language (SQL), Python, and $\mathrm{R}$ language were common programming language skills. A broad framework of integrating informatics competencies, combined with analysis of the skills the jobs needed, and knowledge acquisition based on global health informatics projects guided the development of an online population health informatics curriculum in a rapidly changing technological environment.

Key words: Population health informatics, Workforce, Competencies, Public health, Training, Skills

Correspondence: *ashish.joshi@sph.cuny.edu

DOI: 10.5210/ojphi.v13i1.11517

Copyright (C2021 the author(s)
\end{abstract}


This is an Open Access article. Authors own copyright of their articles appearing in the Online Journal of Public Health Informatics. Readers may copy articles without permission of the copyright owner(s), as long as the author and OJPHI are acknowledged in the copy and the copy is used for educational, not-for-profit purposes.

\subsection{Introduction}

There is a growing need for evidence-driven population health interventions. The emerging science of population health informatics has continually demonstrated significant promise in revolutionizing the delivery of population health interventions. Population health informatics tools and technologies are rapidly enhancing the capacity to translate growing population data into meaningful information that can inform actionable insights. These population health technologies have already shown promise in improving the effectiveness of core public health services such as outbreak detection and control, immunizations and real-time information on health impacts of emergencies [1]. Expertise in population health informatics is critical in supporting the activities of public health agencies toward building and sustaining information capabilities that meet evolving population health needs. Owing to the wealth of public health functions that rely on data assessments and the rapid pace of technological advancements, public health professions require a core set of informatics skills [1]. In addition, health agencies need health informaticians who work at junior and senior organizational levels to oversee the development and implementation of successful IT systems [1].

There are numerous training programs in health informatics in the United States. More than 90 universities provide training in biomedical informatics at certificate, masters and doctoral levels [2]. A plethora of training programs in the field of public health informatics has emerged in the past decade. Compared to the public health informatics programs offered, population health informatics is a relatively recent advancement. Studies have shown that despite the growing volume of training programs in Informatics as well as public health, gaps exist in the competencies of public health graduates in meeting the requisite skills and demands of the dynamic public health workforce [2-4].

In particular, existing workforce assessments have shown that public health professionals across many local health departments lack adequate health informatics skills [5]. A gap analysis of biomedical informatics graduate education competencies identified key topics that were missing from the existing graduate curricula including community health, translational and clinical research, knowledge representation, data mining, communication and evidence-based practice [2]. An initial assessment of existing Public/Population Health Informatics programs that offered certificate, masters and doctoral levels, was conducted [6]. The study explored informatics-training programs currently available to meet the growing demand for a trained workforce in global settings. These programs then matched against the 14 competencies determined by the Centers for Disease Control and Prevention (CDC). These competencies included workforce supporting development of strategic direction for public health informatics within the enterprise, participating in development of knowledge management tools for the enterprise, use informatics standards, ensure that knowledge, information, and data needs of project or program users and stakeholders are met, support information system development, procurement, and implementation that meet public health program needs, manage IT operations related to project or program (for public health 
agencies with internal IT operations), monitor IT operations managed by external organizations, communicate with cross-disciplinary leaders and team members, evaluate information systems and applications, participate in applied public health informatics research for new insights and innovative solutions to health problems, contribute to development of public health information systems that are interoperable with other relevant information systems, support use of informatics to integrate clinical health, environmental risk, and population health, implement solutions that ensure confidentiality, security, and integrity while maximizing availability of information for public health and conduct education and training in public health informatics. Our findings revealed that all the programs addressed at least some of the competencies for Public Health Informatics. The predominant competencies covered included strategy development, interoperability, integration of clinical and population health, knowledge and project management. One of the key findings; however was that none of the Public Health Informatics programs addressed all the CDC competencies [6].

Curriculum is critical to foster effectiveness in higher education [7] both in the short and longterm [8]. Results of previous study has demonstrated the need for curricular change in existing programs to facilitate critical contributions toward assuring clinical, social, and population health $[9,10]$. Variety of approaches to curriculum development predominantly focus on medical school curricula. Six-step approach to curriculum development in medical schools include problem identification and general needs assessment, targeted needs assessment, goals and objectives, educational strategies, and implementation [11]. Another study suggested a 5-step theoretical framework to curriculum development that includes environmental analysis, graduate competencies, curriculum development, pedagogical strategies, and implementation, evaluation, feedback [8]. Informatics curricula defined using educational competencies and requirements based on literature reviews, internet searches, needs assessments and assessments of HIT workforce such as local health departments [12-14]. The International Medical Informatics Association (IMIA) has extended a global perspective on educational competencies with a threedimensional framework of educational needs and recommended course content [15]. Other approaches to curricula development have included a combination of literature reviews, focus groups, and expert panel reviews/decision making by subject-matter experts (including researchers, practitioners and policy makers) to define specific competencies that course evaluations can address [16-19].

While the variety of approaches to curriculum development utilize existing evidence and educational strategies, the majority of these approaches fail to incorporate a workforce skills assessment and integration into curriculum development. Several informatics workforce needs assessments and agendas repeatedly recommend appropriate training and integration of eHealth in existing curricula as methods for addressing the skills gaps in the informatics workforce [5,20-24]. Evaluating health informatics programs will foster effective curricula development that will meet the diverse needs of the informatics workforce [25]. An integrated approach of mapping curriculum competencies to workforce demands can help guide development of curriculum that can specifically address demands of the emerging, fast changing job market and make it possible to review and refine the existing health informatics training program competencies.

The objective of our study is to integrate program specific competencies with analysis of available positions on job search engine "Indeed" to identify population health informatics workforce needs, 
skills and expertise in the state of New York. Findings of the study inform development of an evidence based graduate population health informatics curriculum at CUNY Graduate School of Public Health and Health Policy.

\section{Methods}

We conducted content analysis of the Population Health Informatics related job postings in the state of New York between June and July 2019 using the Indeed job board. Indeed.com is one of the leading job sites. It curates millions of job listings across company career sites, job boards, associations, newspaper classifieds and other online sources [26]. The aim of the search was to characterize the knowledge, skills and expertise required by the employers of the informatics workforce. The search terms included "health informatics" and "population health informatics." The initial search yielded 496 job postings. After removal of duplicates and inactive postings 321 job postings remained. Excluding postings that did not include details of the positions' responsibilities resulted in 306 jobs. Content analysis on the remaining final 306 jobs done. The content analysis process involved an inductive and deductive approach [27]. An inductive approach helped to identify and categorize core job posting information followed by a deductive approach that helped to evaluate the skills and expertise required for specific job categories. Steps include;

1. Identification and reclassification of job titles: Individual reviews of all 306-job postings conducted. Some examples of the job postings included clinical informatics analyst, application analyst, health informatics specialist, and healthcare analytics manager. The 306 job positions were subsequently classified into 14 unique job functions including administrator, analyst, consultant, coordinator, data governance, designer/developer, director, engineer, faculty/researcher, informatics specialist, manager, quality informatics, specialist, and others (representing job functions that did not fit into the listed roles). This involved an iterative deductive process in which related job positions were combined based on job titles and job descriptions. The degrees required/preferred, and experience required/preferred abstracted from the newly created job categories.

2. Extraction and categorization of technical skills: Review of the existing literature on informatics workforce needs identified 44 skills across various informatics jobs in diverse settings [28]. These skills used as a template to identify the skills listed across the job postings in the current study. Seventy-eight skills extracted from the current study. The process of identifying skills involved an extensive and iterative review of each job description and summary details. The final skills $(n=78)$ identified in our study included both new skills from the current postings in addition to skills that had been previously identified $(n=44)$ in the literature. 


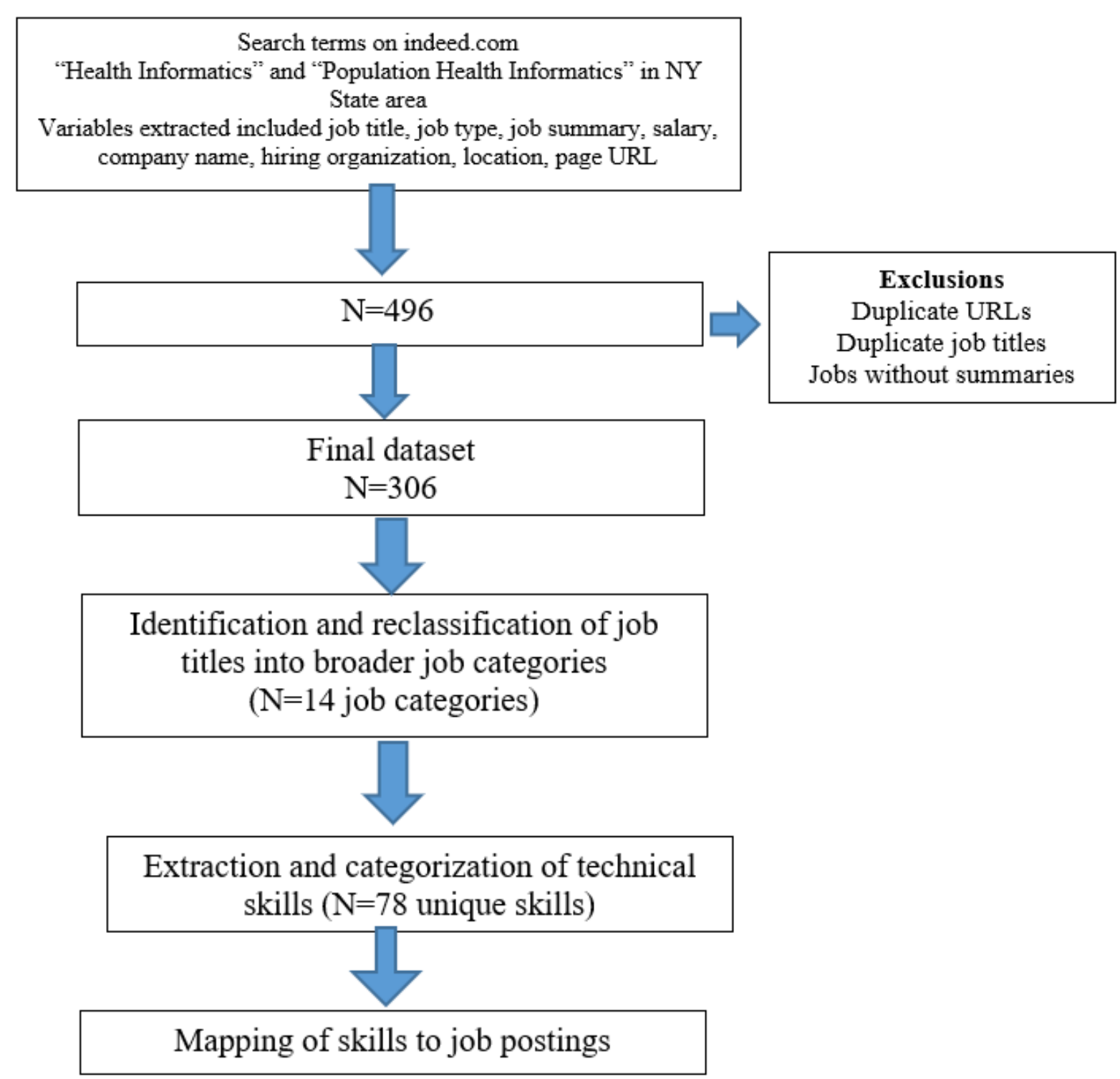

Figure 1. Flow chart describing the job assessment process.

\section{Variable extraction}

Following variables extracted from each job posting and included;

- Job categories: Information recorded from the publicly available job postings and characterized into different categories as analyst, director, faculty/researcher, manager, informatics specialist, designer or developer.

- Hiring organization type: Information recorded from publicly available job postings on the types of organizations where these jobs were available including health system, hospital, academia, pharmacy, and biotechnology/consulting or other. 
- Degree (Required/Preferred): Information was extracted on both required and preferred degree requirements and was characterized into bachelors/ or masters, $\mathrm{PhD}$ and above. Information also recorded if the degree requirements not listed. The required degree requirement reflected the minimal education that the applicant should possess to submit the application for the job.

- Work experience (Required/Preferred): Information recorded on both required and preferred work experience. The work experience characterized as either 1-2 years, 3 to 4 years, 5 to 7 years, 8 to 10 years and 11 to 15 years. In addition, there were job postings that reported as either commensurate with degree or reported as not listed.

- Salary: Information was recorded on salary and income categories included an annual salary of $<\$ 40,000$, followed by several other salary categories including $\$ 40,000$ - $\$ 49,999, \$ 50,000$ - $\$ 60,099, \$ 60,100-\$ 70,099, \$ 70,100$ - $\$ 80,099, \$ 81,000$ $\$ 90,199, \$ 90,200-\$ 123,499, \$ 110,000-\$ 123,549, \$ 123,500+$ and $\$ 145,400$ and above. There were jobs whose salary could not be determined.

- Job type: Information recorded on job types including whether the job postings were contract, full time, internship, art-time or temporary.

- Location: Information recorded on geographic distribution of the population health informatics jobs.

- Knowledge, skills and expertise: Variable information extracted from the job descriptions so that specific knowledge, skills and expertise needed identified.

- Software skills: Analysis performed to determine the most common software skills listed with each job description.

\subsection{Statistical Analysis}

Descriptive statistics computed for the job posting characteristics and skills identified. The results presented as percentages and frequencies. The job postings reclassified into broader categories representing unique job functions. Cross tabulations conducted to examine the degrees required/preferred and experience required/preferred across each of the job categories. Cross tabulations conducted to examine the distribution of skills across the various job categories. SAS text mining used to identify the key terms that used in job description and terms characterized into knowledge, skills and expertise categories. Analysis performed in SAS v 9.4 and Microsoft Excel.

\section{Results}

\subsection{Characteristics of the job postings}

A total 306 job postings evaluated. The job title of the various positions were characterized as analyst $(21 \%, \mathrm{n}=65)$, director $(15 \%, \mathrm{n}=46)$ and faculty/researcher $(14 \%, \mathrm{n}=44)$ (Table 1$)$. These were followed by other titles such as manager $(10 \%, \mathrm{n}=32)$, informatics specialist $(9 \%, \mathrm{n}=26)$, and designer/developers $(8 \%, \mathrm{n}=23)$. More than one-third of the hiring organizations for these jobs were health systems $(35 \%, \mathrm{n}=106)$ followed by hospitals $(19 \%, \mathrm{n}=59)$, and academia $(17 \%, \mathrm{n}=51)$. Almost $100 \%$ of the jobs were fulltime $(n=291)$. Around half the jobs were based in New York City $(47 \%, n=143)$ and $11 \%$ of them were based in Westchester in NY state $(n=33)$. More than half of the jobs listed required either a bachelor's degree as the minimum degree requirement (63\%, 
$\mathrm{n}=192), 13 \%$ masters $(\mathrm{n}=41)$ and $9 \%$ doctoral degree $(\mathrm{n}=26)$. Only $19 \%$ of the listings preferred a master's degree $(\mathrm{n}=58)$. However, $71 \%$ of them did not list the degree preferred.

Almost half of the job listings required that candidates possess 3 to 7 years of experience (44\%, $\mathrm{n}=132)$. Thirteen percent required 1 to 2 years of experience $(\mathrm{n}=40)$. The most common annual salary range for the jobs were $\$ 70,100$ to $\$ 80,099(22 \%, n=68)$, and $\$ 110,000$ to $\$ 123,549(19 \%$, $\mathrm{n}=58$ ). Twelve percent of the jobs had a salary range of $\$ 81,000$ to $\$ 90,199$. Table 1 indicates the majority of jobs were available in New York.

Table 1. Descriptive analysis of the job postings

\begin{tabular}{|c|c|}
\hline Variables assessed & $N=306$ \\
\hline \multicolumn{2}{|l|}{ Job categories } \\
\hline Analyst & $21 \%(\mathrm{n}=65)$ \\
\hline Consultant & $2 \%(\mathrm{n}=7)$ \\
\hline Specialist & $6 \%(n=17)$ \\
\hline Quality informatics & $4 \%(\mathrm{n}=12)$ \\
\hline Coordinator & $4 \%(n=9)$ \\
\hline Data governance & $2 \%(\mathrm{n}=5)$ \\
\hline Director & $15 \%(\mathrm{n}=46)$ \\
\hline Faculty/Researcher & $14 \%(\mathrm{n}=44)$ \\
\hline Manager & $10 \%(\mathrm{n}=32)$ \\
\hline Informatics Specialist & $9 \%(\mathrm{n}=26)$ \\
\hline Designer/Developer & $7 \%(\mathrm{n}=23)$ \\
\hline Other & $6 \%(\mathrm{n}=20)$ \\
\hline \multicolumn{2}{|l|}{ Hiring organization type } \\
\hline Health System & $35 \%(\mathrm{n}=106)$ \\
\hline Hospital & $19 \%(\mathrm{n}=59)$ \\
\hline Academia & $17 \%(\mathrm{n}=51)$ \\
\hline Insurance & $3 \%(\mathrm{n}=8)$ \\
\hline Pharmacy & $9 \%(\mathrm{n}=27)$ \\
\hline Biotechnology & $4 \%(n=13)$ \\
\hline Consulting & $4 \%(n=13)$ \\
\hline Other & $9 \%(\mathrm{n}=29)$ \\
\hline Degree required & \\
\hline
\end{tabular}




\begin{tabular}{|c|c|}
\hline Bachelor's and Above & $63 \%(n=192)$ \\
\hline Master's and Above & $13 \%(\mathrm{n}=41)$ \\
\hline $\mathrm{PhD}$ and $\mathrm{MD}$ or Equivalent & $9 \%(\mathrm{n}=26)$ \\
\hline Advanced degree & $3 \%(n=10)$ \\
\hline Not listed & $12 \%(n=37)$ \\
\hline \multicolumn{2}{|l|}{ Degree preferred } \\
\hline Bachelor's and Above & $2 \%(\mathrm{n}=7)$ \\
\hline Master's and Above & $19 \%(n=58)$ \\
\hline $\mathrm{PhD}$ and $\mathrm{MD}$ or Equivalent & $6 \%(\mathrm{n}=19)$ \\
\hline Advanced Degree & $1 \%(\mathrm{n}=4)$ \\
\hline Not listed & $71 \%(218)$ \\
\hline \multicolumn{2}{|l|}{ Experience required (years) } \\
\hline 1 to 2 years & $13 \%(\mathrm{n}=40)$ \\
\hline 3 to 4 & $1 \%(\mathrm{n}=2)$ \\
\hline 5 to 7 & $22 \%(\mathrm{n}=66)$ \\
\hline 8 to 10 & $4 \%(n=13)$ \\
\hline Commensurate with degree & $3 \%(\mathrm{n}=10)$ \\
\hline Not listed & $36 \%(n=109)$ \\
\hline \multicolumn{2}{|l|}{ Experience preferred (years) } \\
\hline 1 to 2 years & $2 \%(\mathrm{n}=6)$ \\
\hline 3 to 4 & $2 \%(\mathrm{n}=5)$ \\
\hline 5 to 7 & $2 \%(\mathrm{n}=5)$ \\
\hline 8 to 10 & $2 \%(\mathrm{n}=4)$ \\
\hline Not listed & $92 \%(n=286)$ \\
\hline \multicolumn{2}{|c|}{ Salary (based on Indeed estimation) } \\
\hline$<\$ 40,000$ & $1 \%(\mathrm{n}=3)$ \\
\hline$\$ 40,000-\$ 49,999$ & $3 \%(\mathrm{n}=7)$ \\
\hline$\$ 50,000-\$ 60,099$ & $7 \%(\mathrm{n}=22)$ \\
\hline$\$ 60,100-\$ 70,099$ & $8 \%(n=23)$ \\
\hline$\$ 70,100-\$ 80,099$ & $22 \%(\mathrm{n}=68)$ \\
\hline$\$ 81,000-\$ 90,199$ & $12 \%(n=36)$ \\
\hline
\end{tabular}




\begin{tabular}{|c|c|}
\hline$\$ 90,200-\$ 123,499$ & $3 \%(\mathrm{n}=40)$ \\
\hline$\$ 110,000-\$ 123,549$ & $19 \%(\mathrm{n}=58)$ \\
\hline$\$ 123,500+$ & $3 \%(\mathrm{n}=9)$ \\
\hline$\$ 145,400+$ & $1 \%(\mathrm{n}=2)$ \\
\hline NA & $12 \%(\mathrm{n}=38)$ \\
\hline Job Type & $1 \%(\mathrm{n}=3)$ \\
\hline Contract & $95 \%(\mathrm{n}=291)$ \\
\hline Full-Time & $1 \%(\mathrm{n}=2)$ \\
\hline Internship & $3 \%(\mathrm{n}=7)$ \\
\hline Part-time & $1 \%(\mathrm{n}=3)$ \\
\hline Temporary &
\end{tabular}

Location of Jobs: Analysis of the job locations showed that majority of the jobs were available in New York County $(48 \% ; n=145)$ followed by Westchester $(11 \% ; n=33)$, Nassau $(5 \% ; n=15)$ and Suffolk (4\%; $n=13)$ (Figure 2). Ninety -five percent $(n=291)$ of the jobs were full time. Of the 145 jobs available in NY, majority of them were full time $(95 \% ; n=138)$. Similar trends seen across other counties in the NY state. It was found that of the total jobs available in New York County, majority of them $(31 \% ; n=45 / 145)$ were offering salary in the range of $\$ 110,000$ $\$ 123,549 ; 16 \%(n=23)$ offered salary between $\$ 70,100$ - $\$ 80,099$ and $15 \%$ offered $\$ 90,200$ $\$ 123,499$.

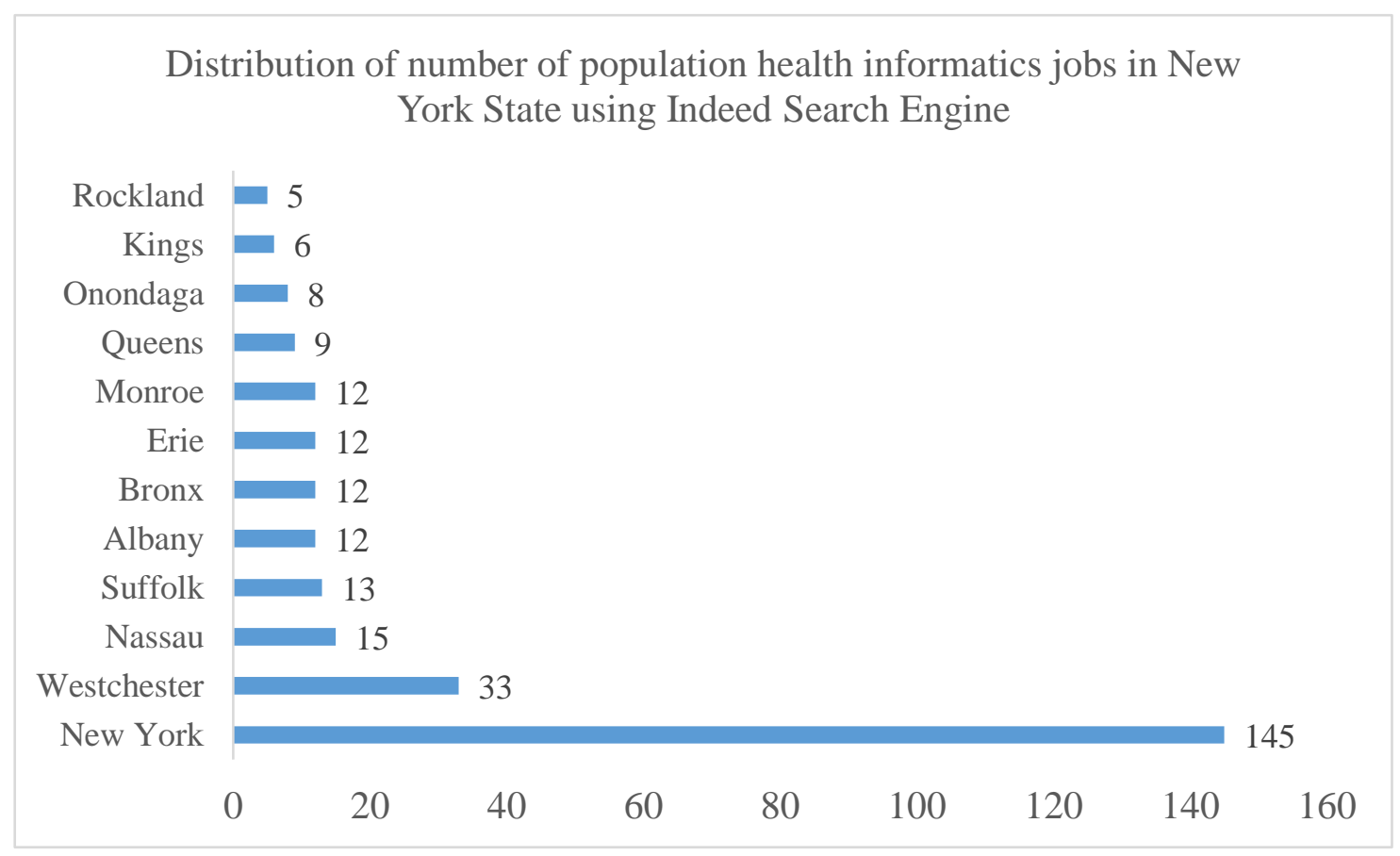

Figure 2. Distribution of population health informatics jobs in New York State 


\subsection{Stratified descriptive analysis of the job postings}

\subsubsection{Degree qualifications required across the job categories}

Eighty-seven percent $(n=57 / 65)$ of the analyst job category postings mentioned the degree requirements required. A hundred percent of coordinator and data governance jobs indicated degree requirements required in their job postings. Less number of consultant and quality informatics jobs had indicated required degree requirements as compared to other job categories (Figure 2).

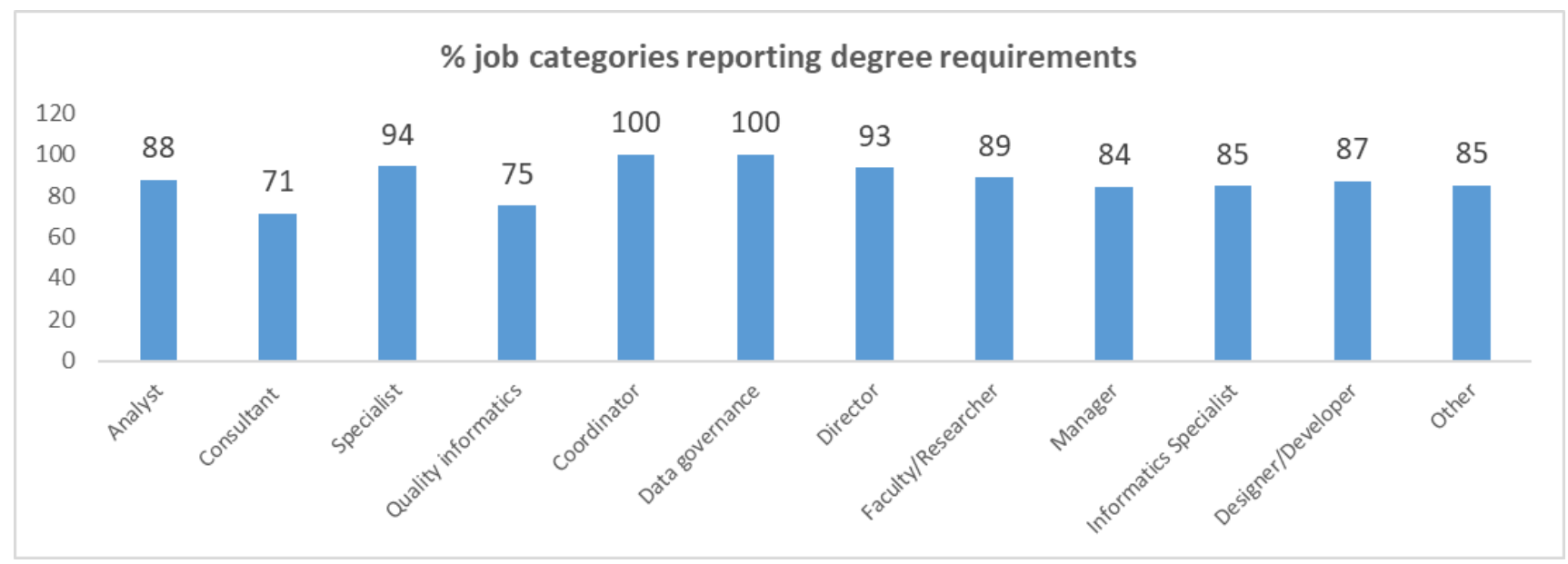

Figure 3. Percentage distribution of job categories reporting degree requirements

Eighty four percent of the postings in the analyst job category required individuals to have bachelors and above degree requirements while $25 \%(n=15)$ of them preferred Master's degree. More than half of the positions in the job category of specialist indicated bachelors and above degree requirements $(69 \% ; n=11 / 16)$ and $31 \%(n=5)$ preferred Master's. Doctoral degree requirements were primarily required for faculty/researcher, director and manager job categories. Nearly $37 \%$ of the director positions preferred Masters.

Table 2. Distribution of degrees required for each of the job categories

\begin{tabular}{|c|c|c|c|c|c|c|c|}
\hline \multirow{2}{*}{$\begin{array}{c}\text { Job Category } \\
\text { Role }\end{array}$} & \multirow{2}{*}{$\begin{array}{l}\text { Total } \\
\text { jobs } \\
(\mathrm{N})\end{array}$} & \multirow{2}{*}{$\begin{array}{c}\text { Reporte } \\
\text { d degree } \\
(\mathbf{N})\end{array}$} & \multicolumn{4}{|c|}{ Required Degree } & \multirow{2}{*}{$\begin{array}{c}\text { Degree } \\
\text { Preferred } \\
\text { Masters }\end{array}$} \\
\hline & & & $\begin{array}{c}\text { Advance } \\
\text { d Degree } \\
(\mathrm{N})\end{array}$ & $\begin{array}{c}\text { Bachelor's } \\
\text { and Above } \\
\text { (N) }\end{array}$ & $\begin{array}{l}\text { Master's } \\
\text { degree and } \\
\text { Above } \\
\text { (N) }\end{array}$ & $\begin{array}{c}\text { PhD and } \\
\text { MD or } \\
\text { equivalent } \\
\text { (N) }\end{array}$ & \\
\hline Analyst & 65 & 57 & 3 & 48 & 6 & & 15 \\
\hline Consultant & 7 & 5 & & 4 & & 1 & 1 \\
\hline
\end{tabular}




\begin{tabular}{|c|c|c|c|c|c|c|c|}
\hline Specialist & 17 & 16 & & 11 & 5 & \\
\hline $\begin{array}{c}\text { Quality } \\
\text { informatics }\end{array}$ & 12 & 9 & & 7 & 1 & 1 & 2 \\
\hline $\begin{array}{c}\text { Coordinator } \\
\text { Data }\end{array}$ & 9 & 9 & 1 & 7 & 1 & & 2 \\
\hline $\begin{array}{c}\text { governance } \\
\text { Director }\end{array}$ & 46 & 43 & 1 & 25 & 9 & 8 & 16 \\
\hline $\begin{array}{c}\text { Faculty/Res } \\
\text { earcher }\end{array}$ & 44 & 39 & & 17 & 10 & 12 & 4 \\
\hline Manager & 32 & 27 & & 20 & 3 & 4 & 6 \\
\hline $\begin{array}{c}\text { Informatics } \\
\text { Specialist }\end{array}$ & 26 & 22 & 3 & 17 & 2 & & 4 \\
\hline $\begin{array}{c}\text { Designer/De } \\
\text { veloper }\end{array}$ & 23 & 20 & 1 & 15 & 4 & & 2 \\
\hline Other & 20 & 17 & 1 & 16 & & & \\
\hline Total & & 306 & & & & & \\
\hline
\end{tabular}

\subsubsection{Knowledge, skills and expertise required across the job postings}

Data/statistical analysis $(68 \%, \mathrm{n}=207)$, collaboration/working in multidisciplinary teams $(35 \%$, $\mathrm{n}=108)$, biomedical/clinical experience $(30 \%, \mathrm{n}=93)$, electronic health record/electronic medical record $(28 \%, \mathrm{n}=85)$, and communicating findings/delivering actionable results $(275, \mathrm{n}=-82)$ were the most common skills required across various job postings (Table 3 ). Around $20 \%$ of the jobs required skills in management/organization $(23 \%, \mathrm{n}=71)$, consumer-centric/patient outcome knowledge $(23 \%, \mathrm{n}=71)$, data governance/standards/quality skills $(22 \%, \mathrm{n}=67)$, performance improvement $(22 \%, \mathrm{n}=66)$, data manipulation $(21 \%, \mathrm{n}=64)$, and quality measures $(21 \%, \mathrm{n}=65)$ (Figure 4) 


\section{\% Distribution of knowledge, skills and expertise required for various job categories}

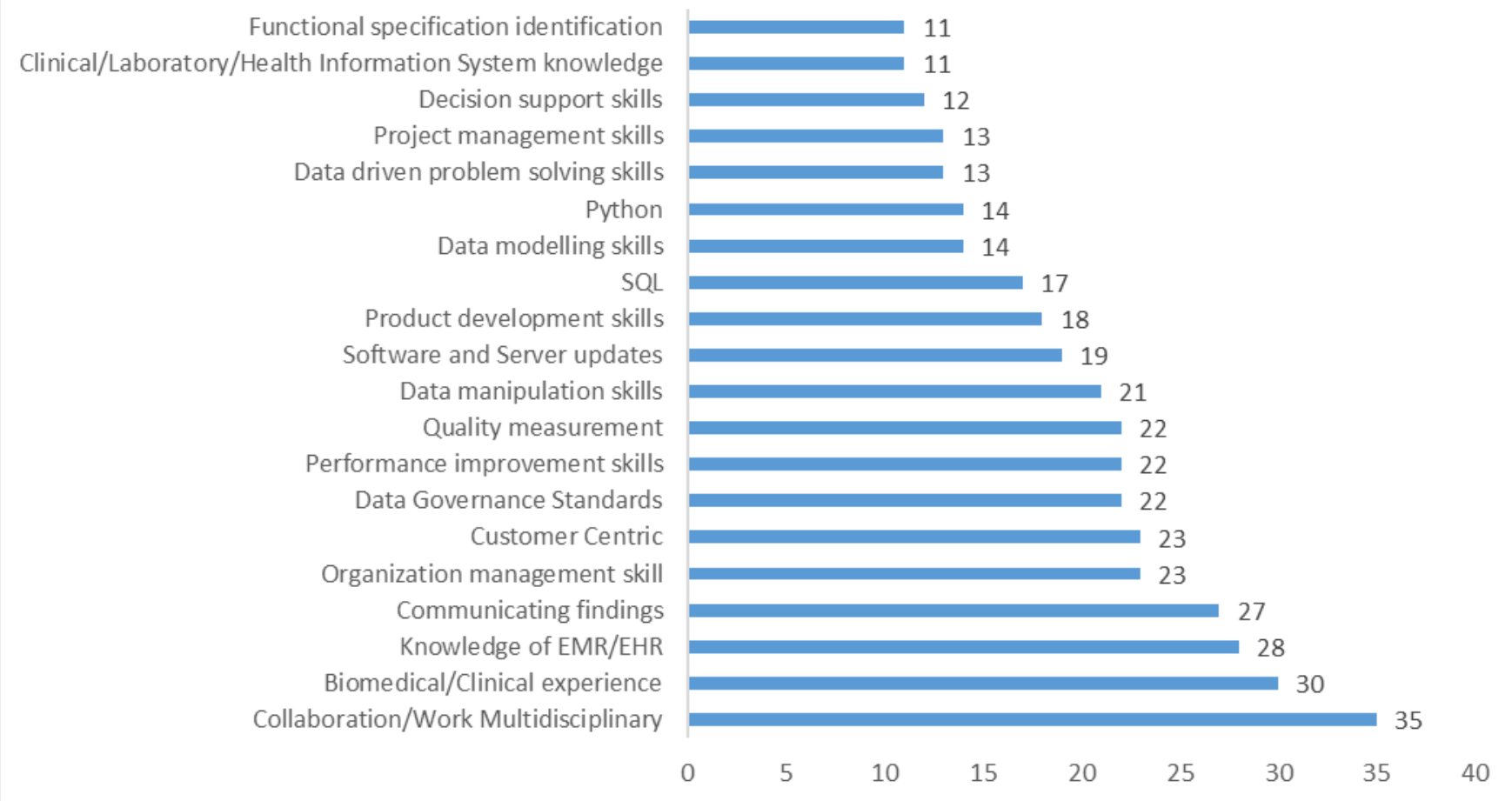

Figure 4. Percentage distribution of knowledge, skills and expertise required for various job categories

Other knowledge, skills and expertise included familiarity with R language (10\%; $\mathrm{n}=32$ ), MS Office (10\%; $n=32)$, SAS (9\%; $n=28)$ and familiarity with HL7 knowledge (8\%; $n=23)$. Some of the other skills included digital health knowledge $(8 \% ; n=23)$, innovative skills $(8 \% ; n=23)$, identifying business problem skills $(7 \% ; \mathrm{n}=21)$, and data management platforms $(7 \% ; \mathrm{n}=22)$. Other technology skills included java script $(8 \% ; n=21), \mathrm{C}++(5 \% ; \mathrm{n}=16)$, dashboard skills such tableau $(5 \% ; n=14)$, machine learning and requirement analysis skills $(4 \% \mathrm{n}=12)$.

\subsubsection{Distribution of skills required across the job categories}

Data/statistical analysis skills were mostly required by analysts $(26 \%, \mathrm{n}=51)$, directors $(15 \%$, $\mathrm{n}=31)$ and faculty/researchers $(12 \%, \mathrm{n}=25)$ (Figure 4). Skill in collaboration/working in multidisciplinary teams was most commonly required among analysts $(23 \%, \mathrm{n}=25)$ and directors $(21 \%, \mathrm{n}=23)$. Biomedical/clinical experience and EHR/EMR knowledge were most commonly required among analysts $(22 \%, \mathrm{n}=20 ; 22 \%, \mathrm{n}=19)$ and informatics specialists $(18 \%, \mathrm{n}=17 ; 18 \%$, $\mathrm{n}=15)$. Management/organizational skills were mostly required among directors $(24 \%, \mathrm{n}=17)$, analysts $(18 \%, \mathrm{n}=13)$, and managers $(14 \%, \mathrm{n}=10)$. The least common skills included dashboards (4\%, $\mathrm{n}=13)$, machine learning $(4 \%, \mathrm{n}=12)$, developing algorithms $(2 \%, \mathrm{n}=6)$, prioritization/resource planning $(1 \%, n=4)$, and population health skills $(1 \%, n=3)$ were mostly required by analysts, faculty/researchers, managers, and quality informatics professionals. 


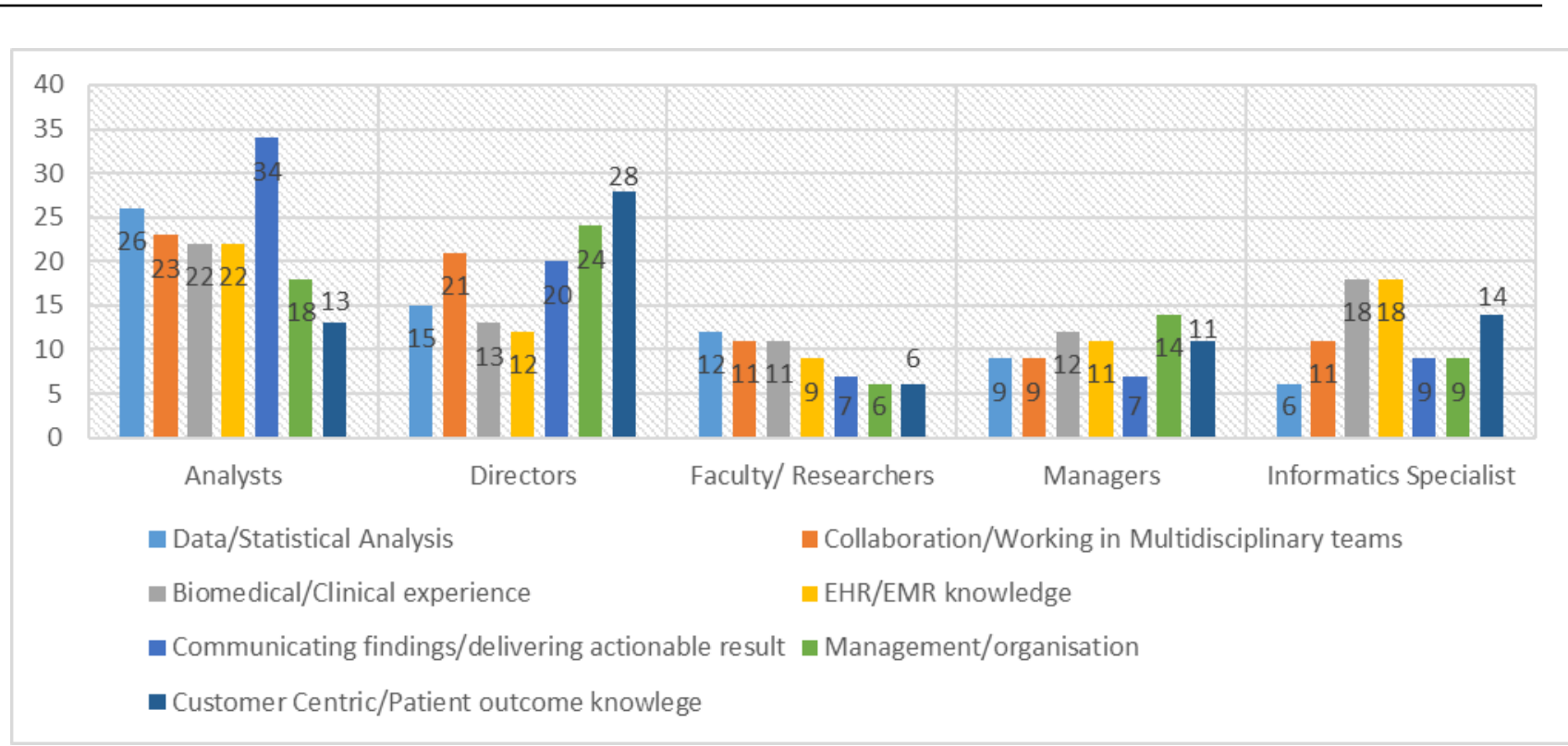

Figure 5. Percentage distribution of skills required across the job categories

\subsubsection{Software skills required across the job categories}

Structured query language (SQL) $(15 \%, \mathrm{n}=46)$, Python $(14 \%, \mathrm{n}=44)$, and R language $(11 \%, \mathrm{n}=33)$ were the most common programming language requirements. MS Office $(10 \%, n=31)$ and Tableau $(5 \%, \mathrm{n}=15)$ were the most common data visualization tool skills required. Less than ten percent of the job postings mentioned experience with SAS $(9 \%, n=27)$, and Java $(8 \%, n=24)$. The most common relational database management skills required across the postings included Microsoft SQL server $(5 \%, \mathrm{n}=14)$ and Oracle $(4 \%, \mathrm{n}=11)$.

SQL was most common software skill mentioned among the 65 positions characterized as Analyst $(35 \%, n=23)$, followed by SAS (22\%; $n=14)$ and R (22\%; $n=14)$. Skills in Python $(15 \% ; n=10)$, MS Office $(15 \% ; \mathrm{n}=10)$ and tableau were additional skills reported for the job category of analyst. Similarly, Python (17\%; n=2), R (17\%; n=2), SQL (17\%; $n=2)$ and MS Office $(17 \% ; n=2)$ were commonly reported skills for the job category Quality Informatics. Python skills were most commonly reported also for the job categories such as data governance $(40 \% ; n=2)$ and designer/developer $(43 \% ; n=10)$, coordinator $(22 \% ; n=2)$ and informatics specialist $(15 \% ; n=4)$ (Figure 6). 


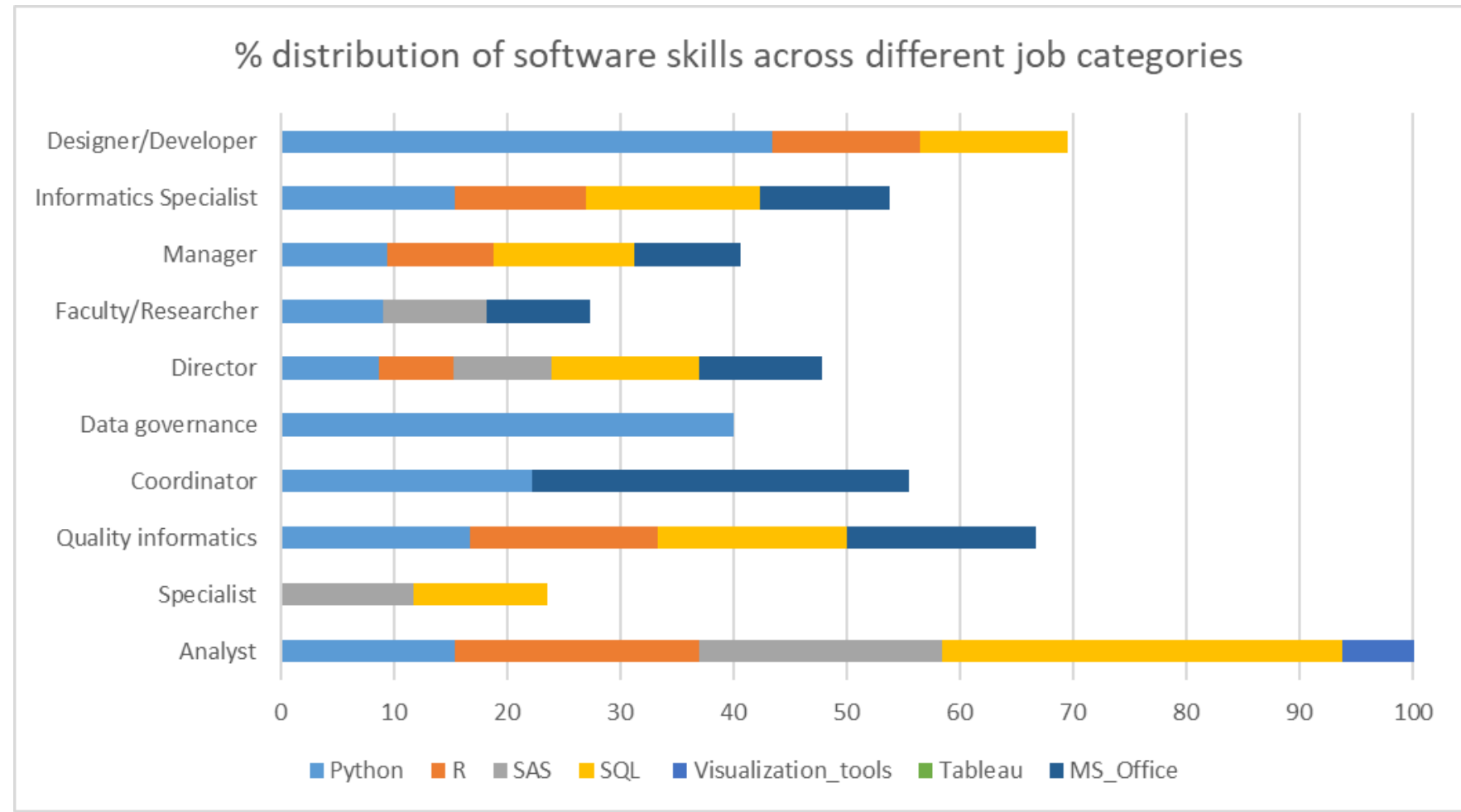

Figure 6. Software skill requirements across job postings.

\subsubsection{Time commitment required across the job categories, and by location.}

Almost all the job postings required a full-time commitment (95\%, $\mathrm{n}=291$ out of 306) (Table 2). Analysts $(21 \%, \mathrm{n}=64)$, director $(15 \%, \mathrm{n}=46)$, faculty/researcher $(13 \%, \mathrm{n}=39)$, and manager $(10 \%$, $\mathrm{n}=31$ ) were the most common full-time jobs. Other less common full-time positions included informatics specialists $(8 \%, \mathrm{n}=26)$, designer/developer $(7 \%, \mathrm{n}=22)$, and specialists $(5 \%, \mathrm{n}=16)$.

Around half of the full-time jobs $(48 \%, n=138)$ were based in New York. Eleven percent $(n=32)$ of the full time jobs were based in Westchester. Additional full-time jobs were available in Nassau $(5 \% ; n=15)$, followed by Albany $(4 \% ; n=12)$, Bronx $(4 \% ; n=12)$, Monroe $(4 \% ; n=12)$, Suffolk $(4 \% ; n=12)$, Erie $(4 \% ; n=12)$ and Queens $(3 \% ; n=8)($ Table 3$)$.

Table 3. Time commitment by job location

\begin{tabular}{|l|c|c|c|c|c|c|}
\hline & $\begin{array}{c}\text { Total } \\
(\mathbf{N}=\mathbf{3 0 6})\end{array}$ & Contract & $\begin{array}{c}\text { Full- } \\
\text { time }\end{array}$ & Internship & $\begin{array}{c}\text { Part- } \\
\text { time }\end{array}$ & Temporary \\
\hline Albany & $\mathbf{N}=\mathbf{1 2}$ & & $\mathbf{N}=\mathbf{1 2}$ & & \\
\hline Bronx & $\mathrm{N}=12$ & & $\mathrm{~N}=12$ & & \\
\hline Brooklyn & $\mathrm{N}=6$ & & $\mathrm{~N}=6$ & & \\
\hline Broome & $\mathrm{N}=2$ & & $\mathrm{~N}=2$ & & \\
\hline
\end{tabular}




\begin{tabular}{|c|c|c|c|c|c|c|}
\hline Clinton & $\mathrm{N}=1$ & & $\mathrm{~N}=1$ & & & \\
\hline Columbia & $\mathrm{N}=3$ & & $\mathrm{~N}=3$ & & & \\
\hline Dutchess & $\mathrm{N}=3$ & & $\mathrm{~N}=3$ & & & \\
\hline Erie & $\mathrm{N}=12$ & $\mathrm{~N}=1$ & $\mathrm{~N}=10$ & & $\mathrm{~N}=1$ & \\
\hline Herkimer & $\mathrm{N}=1$ & & & & $\mathrm{~N}=1$ & \\
\hline Monroe & $\mathrm{N}=12$ & & $\mathrm{~N}=12$ & & & \\
\hline Nassau & $\mathrm{N}=15$ & & $\mathrm{~N}=15$ & & & \\
\hline New York & $\mathrm{N}=145$ & $\mathrm{~N}=1$ & $\mathrm{~N}=138$ & $\mathrm{~N}=2$ & $\mathrm{~N}=2$ & $\mathrm{~N}=2$ \\
\hline Oneida & $\mathrm{N}=1$ & & $\mathrm{~N}=1$ & & & \\
\hline Onondaga & $\mathrm{N}=6$ & & $N=5$ & & $\mathrm{~N}=1$ & \\
\hline Queens & $\mathrm{N}=9$ & $\mathrm{~N}=1$ & $\mathrm{~N}=8$ & & & \\
\hline Rensselaer & $\mathrm{N}=1$ & & $\mathrm{~N}=1$ & & & \\
\hline Rockland & $\mathrm{N}=5$ & & $\mathrm{~N}=4$ & & $\mathrm{~N}=1$ & \\
\hline Saratoga & $\mathrm{N}=2$ & & $\mathrm{~N}=2$ & & & \\
\hline Schenectady & $\mathrm{N}=3$ & & $\mathrm{~N}=3$ & & & \\
\hline St. Lawrence & $\mathrm{N}=2$ & & $\mathrm{~N}=2$ & & & \\
\hline Suffolk & $\mathrm{N}=13$ & & $\mathrm{~N}=12$ & & $\mathrm{~N}=1$ & \\
\hline Tompkins & $\mathrm{N}=2$ & & $\mathrm{~N}=2$ & & & \\
\hline Ulster & $\mathrm{N}=1$ & & $\mathrm{~N}=1$ & & & \\
\hline Warren & $\mathrm{N}=2$ & & $\mathrm{~N}=2$ & & & \\
\hline Westchester & $\mathrm{N}=33$ & & $\mathrm{~N}=32$ & & & $\mathrm{~N}=1$ \\
\hline Yates & $\mathrm{N}=1$ & & $\mathrm{~N}=1$ & & & \\
\hline
\end{tabular}

\subsubsection{Expected salaries across the job categories, and by location}

The annual salary range for majority of the analyst job categories was $\$ 70,100-\$ 80,099$ (31\%; $\mathrm{n}=20)$ followed by $17 \%(\mathrm{n}=11)$ having a salary range of $\$ 60,100-\$ 70,099$ (Figure 7$)$. Of the seven consultant job positions, most of them were in a salary range of $\$ 90,200-\$ 123,499$ (43\%; $n=3)$. Of the seventeen positions in the specialist job category, $35 \%(\mathrm{n}=6)$ of them had a salary range of $\$ 70,100$ - $\$ 80,099$ while $23 \%(n=4)$ had a salary range of $\$ 50,000-\$ 60,099$. Similarly, for other positions advertised across different job categories such as quality informatics $(33 \% ; n=4)$, coordinator $(33 \% ; n=3)$, faculty/researcher $(25 \% ; n=11)$, and informatics specialist $(35 \% ; n=9)$, the salary range was $\$ 70,100$ - $\$ 80,099$. However, majority of the positions in the job category of Director $(48 \% ; n=22)$ or Designer/Developer $(26 \% ; n=6)$ had an annual salary range of $\$ 110,000$ - $\$ 123,549$. 


\section{Most common salary distribution among various job categories (\%)}

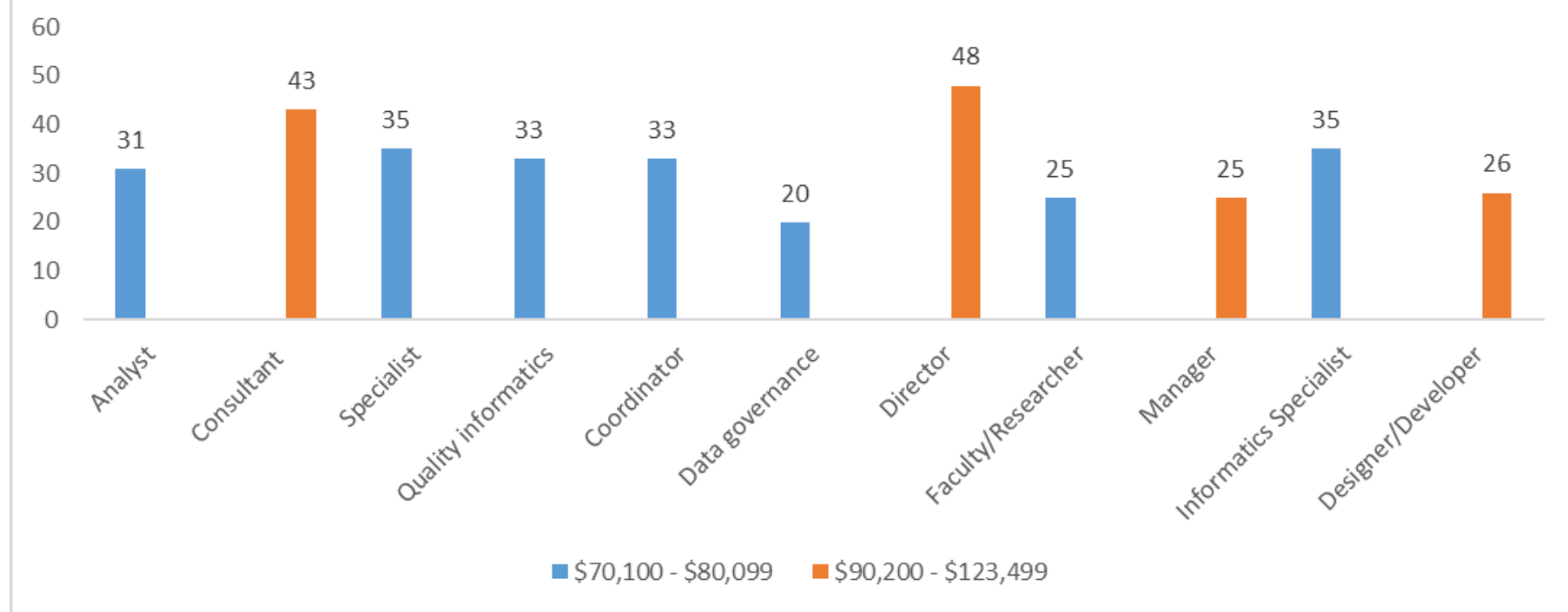

Figure 7. Percentage distribution of most common salary distribution among various job categories

Thirty-two percent $(\mathrm{N}=45)$ of the jobs in the New York County were in the salary range of $\$ 110,000-\$ 123,549,17 \%(n=23)$ in the salary range of $\$ 70,100-\$ 80,099,16 \%(n=22)$ in the salary range of $\$ 90,200$ - $\$ 123,499$. Similarly, in Westchester county, 31\% $(n=10)$ of the jobs had a salary range of $\$ 70,100$ - $\$ 80,099$. Study findings demonstrate skills that are essential to fulfill the population health informatics job needs. Table 4 demonstrates how skills often listed as required or desired for positions in population health informatics. Findings of this study utilized to inform the design and development of a population heath informatics curriculum.

Table 4. Skills prioritized by employers mapped to competencies and incorporated into the curriculum

\begin{tabular}{|c|c|c|}
\hline $\begin{array}{l}\text { Example of Skills } \\
\text { identified in job } \\
\text { postings }\end{array}$ & Informatics Competency & Public Health competency \\
\hline $\begin{array}{c}\text { Working in } \\
\text { multidisciplinary teams }\end{array}$ & $\begin{array}{l}\text { Assess stakeholder data, information, and } \\
\text { knowledge needs }\end{array}$ & $\begin{array}{l}\text { Perform effectively on } \\
\text { interprofessional teams }\end{array}$ \\
\hline Requirement skills & $\begin{array}{l}\text { Design, develop, and implement } \\
\text { user-centered population health } \\
\text { information systems effectively }\end{array}$ & $\begin{array}{l}\text { Propose strategies to identify } \\
\text { stakeholders and build } \\
\text { coalitions and partnerships for } \\
\text { influencing public health } \\
\text { outcomes }\end{array}$ \\
\hline Consumer-centric & $\begin{array}{l}\text { Establish frameworks for evaluating } \\
\text { the implementation process of } \\
\text { information systems and } \\
\text { applications, and make }\end{array}$ & \\
\hline
\end{tabular}




\begin{tabular}{|c|c|c|}
\hline & $\begin{array}{l}\text { recommendations to improve user } \\
\text { satisfaction and outcomes }\end{array}$ & \\
\hline Data management & $\begin{array}{l}\text { Assess stakeholder data, information, and } \\
\text { knowledge needs }\end{array}$ & $\begin{array}{l}\text { Select quantitative \& qualitative } \\
\text { data collection methods appropriate } \\
\text { for a given public health context }\end{array}$ \\
\hline Data/statistical analysis & $\begin{array}{l}\text { Establish frameworks for evaluating the } \\
\text { implementation process of information } \\
\text { systems and applications, and make } \\
\text { recommendations to improve user } \\
\text { satisfaction and outcomes }\end{array}$ & $\begin{array}{l}\text { Select quantitative \& qualitative data } \\
\text { collection methods appropriate for a } \\
\text { given public health context } \\
\text { Interpret results of data analysis for } \\
\text { public health research, policy or } \\
\text { practice. }\end{array}$ \\
\hline Electronic health record & $\begin{array}{l}\text { Design, develop, and implement } \\
\text { user-centered population health } \\
\text { information systems effectively }\end{array}$ & $\begin{array}{l}\text { Design a population-based policy, } \\
\text { program, project or intervention }\end{array}$ \\
\hline Communicating findings & $\begin{array}{l}\text { Design, develop, and implement user- } \\
\text { centered population health } \\
\text { information systems effectively }\end{array}$ & $\begin{array}{l}\text { Select communication strategies for } \\
\text { different audiences and sectors } \\
\text { Describe the importance of cultural } \\
\text { competence in communicating public } \\
\text { health content } \\
\text { Communicate audience-appropriate } \\
\text { public health content, both in writing } \\
\text { and through oral presentation }\end{array}$ \\
\hline $\begin{array}{l}\text { Management/organization } \\
\text { skills }\end{array}$ & $\begin{array}{l}\text { Manage and direct health informatics } \\
\text { planning for projects related to public } \\
\text { health and information technology }\end{array}$ & $\begin{array}{l}\text { Apply principles of leadership, } \\
\text { governance and management, which } \\
\text { include creating a vision, empowering } \\
\text { others, fostering collaboration and } \\
\text { guiding decision making }\end{array}$ \\
\hline Data governance & $\begin{array}{l}\text { Recommend strategies and } \\
\text { solutions that integrate } \\
\text { informatics knowledge within } \\
\text { organizations and communities } \\
\text { and ensure confidentiality, } \\
\text { security, and integrity }\end{array}$ & $\begin{array}{l}\text { Discuss multiple dimensions of the } \\
\text { policy-making process, including the } \\
\text { roles of ethics and evidence }\end{array}$ \\
\hline Standards & $\begin{array}{l}\text { Apply informatics standards } \\
\text { appropriately and contribute to } \\
\text { standards development efforts }\end{array}$ & \\
\hline $\begin{array}{l}\text { Familiarity with HL7 } \\
\text { knowledge }\end{array}$ & $\begin{array}{l}\text { Apply informatics standards } \\
\text { appropriately and contribute to } \\
\text { standards development efforts }\end{array}$ & \\
\hline
\end{tabular}




\begin{tabular}{|c|c|c|}
\hline Innovation & $\begin{array}{c}\text { Manage and direct health informatics } \\
\text { planning for projects related to public } \\
\text { health and information technology } \\
\text { Recommend strategies and solutions } \\
\text { that integrate informatics knowledge } \\
\text { within organizations and } \\
\text { communities }\end{array}$ & $\begin{array}{c}\text { Apply systems thinking tools to a } \\
\text { public health issue } \\
\text { Assess population needs, assets and } \\
\text { capacities that affect communities' } \\
\text { health }\end{array}$ \\
\hline $\begin{array}{c}\text { Dashboard/Data } \\
\text { Visualization }\end{array}$ & $\begin{array}{c}\text { Design, develop, and implement user- } \\
\text { centered population health } \\
\text { information systems effectively }\end{array}$ & $\begin{array}{c}\text { Communicate audience-appropriate } \\
\text { public health content, both in writing } \\
\text { and through oral presentation }\end{array}$ \\
\hline Tableau, Python and MS & $\begin{array}{c}\text { Design, develop, and implement } \\
\text { user-centered population health } \\
\text { information systems effectively }\end{array}$ & $\begin{array}{c}\text { Analyze quantitative and qualitative } \\
\text { data using biostatistics, informatics, } \\
\text { computer-based programming and } \\
\text { software, as appropriate }\end{array}$ \\
\hline
\end{tabular}

Job analysis combined with competencies drawn from various sources such as Council on Education for Public Health (2016 CEPH) [29] criteria, AMIA working group pre-symposium [30] and public health informatics competencies created by the Center for Disease Control [31] and knowledge acquisition through global implementation of informatics projects utilized to design and develop the MS population health informatics curriculum (Figure 8). Core competencies included both public health and Population Health Informatics. Public health competencies [31] were addressed through the required MPH curriculum courses and integrated to informatics competencies through a wide range of course offerings including fundamentals of population health informatics, design and development of population health information systems, surveillance systems and applications of population health informatics, mobile health, population health dashboards, and monitoring and evaluation.

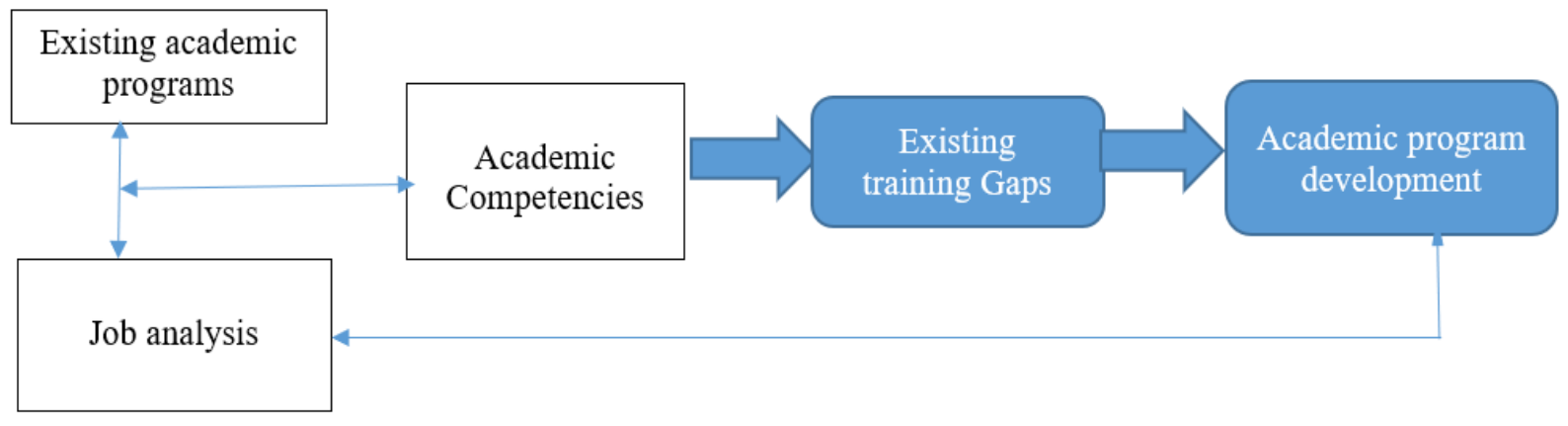

Figure 8. An Integrated approach to academic program development:

The Graduate School of Public Health and Health Policy (SPH) of the City University of New York established first of its kind, Master of Science (MS) in Population Health Informatics, effective fall 2019. The program emphasis on how to design, develop, implement, and evaluate 
technological interventions and innovations using data driven, evidence-based approaches to guide policy making for the improvement of population health outcomes. While most programs, take a hospital-centric approach, the program primarily focuses on how to operationalize informatics solutions to address important public health challenges influencing individuals, families, communities, and the environment in which they live.

The MS program in population health informatics is an online, 39 graduate-level credits program including 15 credits of public health coursework, 18 credits of coursework in health informatics, and 6 credits of a dual practice/culminating experience. The purpose of the Master of Science in Population Health Informatics is to equip students with an in-depth understanding of informatics that supports the development of interventions addressing $21^{\text {st }}$ century public health challenges. Students will acquire the skills necessary to apply technology at the intersection of clinical care and health sciences, strengthening preventive care at the population level. The five public-health specific courses will cover the public health competencies, adopted from the Council on Education for Public Health (CEPH). The three credit each six-concentration courses include Fundamentals of Population Health Informatics, Principles of Consumer Health Informatics, Applications of Population Health Informatics, Population Health Dashboards, Design, development and evaluation of Health technologies and Mobile Health Interventions. The program also offers practicum/Culminating experience. The practicum involves workshop approach where students not only work on their informatics projects but also acquire skills in the areas of MS SQL, Python, data visualization tools such as Excel and Tableau, API, HTML and android toolkit as these skills broadly identified to be critical in the job analysis that conducted. Through this project and the portfolio, students demonstrate their ability to integrate and synthesize the knowledge and skills they have attained in the program.

\section{Discussion}

Education continues to advance, driven by a combination of changes in the practice domain, theoretical developments, and workplace demands [32]. Curricula evolve over time, both because of the newness of the field and in response to the job market. There is an increased focus on public health information and knowledge management systems highlighting need for public health professionals skilled in designing and implementing these systems. Prior study has shown that four competency sets adequately represented in public health informatics curriculum including Leadership and System Thinking Skills, followed by Financial Planning and Management Skills, Community Dimensions of Practice Skills, and Policy Development/Program Planning Skills [33]. In another prior study, the public health informatics design focused on public health core competencies and organization/systems/information sciences related to analyzing, designing, implementing, and disseminating effective information systems in public health [34].

Though many theoretical frameworks and competency guidelines proposed for informatics education, less attention paid to informatics education using analysis of the jobs available today. Results of our study helped identify knowledge, skills and expertise that match employer requirements and ensuring that curriculum meet those requirements in this rapidly changing job market. Our study combined competencies and analyzed job skills as an integrated approach to design and develop our curriculum. This is a perspective that has been lacking in previous literature 
on this topic. There are a growing number of 'informatics' programs, but they vary substantially by academic level and focus [32]. This suggests studying existing educational programs and their curricula, and examining how such knowledge can contribute to defining the informatics professions.

Results of our study show that analyst was the most common job category, followed by director and faculty/researcher. Population Health Informatics professionals work in practice, research, or academia and whose primary work function is to use informatics to improve the health of populations. Results of our study showed that most common hiring organizations were health system and hospitals followed by academic institutes. Recent studies highlight the need for informatics training in the public health workforce [35]. Similarly, the Council on Education for Public Health (CEPH) includes informatics as a foundational competency for accreditation of public health programs. The need for public health education programs informed by current public health needs and employment opportunities long noted.

More than half of the jobs required bachelors and above. However, $12 \%$ of the jobs did not list the degree required for the particular job. Nineteen percent of the jobs listed indicated masters as the preferred while more than half of the jobs did not list the degree preferred. However, there are still significant gaps in workforce skills training. Studies examining students' perspectives on required skill sets are limited. Academicians, students, employers, and people working in the health care industry have different perspectives and priorities for required informatics skills. Identifying health informatics skill sets for graduate students has always been a challenge.

Health informatics programs should consider specialized tracks that include specific skills to meet the complex health care delivery and market demand, and specific training components defined for different specialties. The specific skill sets required by different employers vary owing to the increasing rate of technological developments. Results of our study showed Python, MS SQL and Tableau as one of the most common technical skills desired in these job openings. In addition, the skills needed for health informaticians vary significantly depending on the position, and health informatics students need skills pertinent to their professional experience for their future career paths [32]. Requirements use cases, and business process definitions produced by systems analysis and require expertise in the system development life cycles.

Our study also showed that various job categories required requirement analysis, business processes and working in multidisciplinary teams skills. International Medical Informatics Association (IMIA) determined 3 domains and 12 learning outcomes that related to data training and skills. These learning outcomes focus on health data management principles; structure and design principles of health records; principles of data representation and analysis; ethical and security issues; nomenclatures, vocabularies, terminologies, ontologies, and taxonomies; health administration and economics; basic informatics terminology; ability to communicate electronically; and methods of practical and theoretical informatics, mathematics, biometry, and epidemiology. There are several international and national initiatives developing health informatics competencies, determining the standard comprehensive health information skill sets has always been a challenging task because of the continually evolving technology. New job opportunities for health informatics professionals require specific skill sets to utilize new cuttingedge, patient-focused delivery tools. 
The major limitation of this study is its specificity to one geographical area. While it is probable that similar results found for other urban areas, with similar demographics, other areas may have different employee needs. A larger study including wider and more representative geographical areas needed to generalize findings to broader population areas. Another limitation is that the position listings examined were from one source such as Indeed. These may not be representative of all the positions available to people with degrees in population health informatics. We are expanding the current framework by conducting analysis of the additional jobs available globally across other platforms that will help to formulate various skills needed in this rapidly evolving field of population health informatics.

Population health informatics curriculum designed and developed took into account various available program specific competencies and integrated knowledge, skills and expertise based on the analysis of the job positions. We will assess the skills of the students using a wide range of methods including case study scenarios, evaluation of existing health information systems, designing and developing health information systems, and project management skills through independent project practicum. In addition, feedback from student preceptors obtained. Academicians have also been discussing the integration of skills training into the health informatics curriculum for a long time. Faculty members who work in academic institutions, health informatics departments, and programs expected to follow up on the changing requirements and update the content of their curriculum continuously. Results of this pilot study can serve as a framework to guide the development of a curriculum by the various academic units, and program directors based on this integrated approach. The framework can also guide evaluation of academic programs on an ongoing basis to identify skills that would be essential for students to acquire and make them job ready in this rapidly changing environment.

\section{References}

1. Miller C, Ishikawa C, DeLeon M, Huang M, Ising A, et al. 2015. Joint Recommendations for the Public Health Informatics Infrastructure. J Public Health Manag Pract. 21(5), 51618. PubMed https://doi.org/10.1097/PHH.0000000000000325

2. Ritko AL, Odlum M. 2013. Gap analysis of biomedical informatics graduate education competencies. AMIA Annu Symp Proc. 2013, 1214-23. PubMed

3. Fleming ML, Parker E, Gould T, Service M. 2009. Educating the public health workforce: Issues and challenges. Aust New Zealand Health Policy. 6, 8. PubMed https://doi.org/10.1186/1743-8462-6-8

4. Gaba A, Shrivastava A, Amadi C, Joshi A. 2015. The Nutrition and Dietetics Workforce Needs Skills and Expertise in the New York Metropolitan Area. Glob J Health Sci. 8(6), 1424. PubMed https://doi.org/10.5539/gjhs.v8n6p14

5. Shah GH, Leider JP, Castrucci BC, Williams KS, Luo H. 2016. Characteristics of Local Health Departments Associated with Implementation of Electronic Health Records and Other Informatics Systems. Public Health Rep. 131(2), 272-82. PubMed https://doi.org/10.1177/003335491613100211 
6. Joshi A, Perin DM. Gaps in the existing public health informatics training programs: a challenge to the development of a skilled global workforce. Perspect Health Inf Manag. 2012; 9(fall):1-13. Epub 2012 Oct 1. PMID: 23209452; PMCID: PMC3510646.

7. Rosemary D. 2005. Engaging the Curriculum in Higher Education. Int Stud Sociol Educ. 15, 107-12. https://doi.org/10.1080/0962021980020157

8. Khan M, Law L. 2015. An Integrative Approach to Curriculum Development in Higher Education in the USA: A Theoretical Framework. Int Educ Stud. 8(3), 66-76. https://doi.org/10.5539/ies.v8n3p66

9. Brownson RC, Samet JM, Chavez GF, Davies MM, Galea S, et al. 2015. Charting a future for epidemiologic training. Ann Epidemiol. 25(6), 458-65. PubMed https://doi.org/10.1016/j.annepidem.2015.03.002

10. Patel SG, Keswani R, Elta G, Saini S, Menard-Katcher P, et al. 2015. Status of CompetencyBased Medical Education in Endoscopy Training: A Nationwide Survey of US ACGMEAccredited Gastroenterology Training Programs. Am J Gastroenterol. 110(7), 956-62. PubMed https://doi.org/10.1038/ajg.2015.24

11. Thomas PA, Kern D, Hughes MT, Chen BY. Curriculum development for medical education: A six-step approach. John Hopkins University Press. 2015. 1-300.

12. Huang QR. 2007. Competencies for graduate curricula in health, medical and biomedical informatics: a framework. Health Informatics J. 13(2), 89-103. PubMed https://doi.org/10.1177/1460458207076465

13. Hersh W. 2010. The health information technology workforce: estimations of demands and a framework for requirements. Appl Clin Inform. 1(2), 197-212. PubMed https://doi.org/10.4338/ACI-2009-11-R-0011

14. Hersh W, Wright A, Garets D, Davis M, Pilolla L. Characterizing the health information technology workforce: Analysis from the HIMSS Analytics ${ }^{\text {TM }}$ database. 2008 Portland, OR: http://www billhersh info/\# workforce.

15. Mantas J, Ammenwerth E, Demiris G, Hasman A, Haux R, et al. 2010. IMIA Recommendations on Education Task Force. Recommendations of the International Medical Informatics Association (IMIA) on Education in Biomedical and Health Informatics. First Revision. Methods Inf Med. 49(2), 105-20. PubMed https://doi.org/10.3414/ME5119

16. Jogerst K, Callender B, Adams V, Evert J, Fields E, et al. 2015. Identifying interprofessional global health competencies for 21st-century health professionals. Ann Glob Health. 81(2), 239-47. PubMed https://doi.org/10.1016/j.aogh.2015.03.006

17. Tabak RG, Padek MM, Kerner JF, Stange KC, Proctor EK, et al. 2017. Dissemination and Implementation Science Training Needs: Insights from Practitioners and Researchers. Am J Prev Med. 52(3) (Suppl 3), S322-29. PubMed https://doi.org/10.1016/j.amepre.2016.10.005 
18. Pruitt Z, Mhaskar R, Kane BG, Barraco RD, DeWaay DJ, et al. 2017. Development of a health care systems curriculum. Adv Med Educ Pract. 8, 745-53. PubMed https://doi.org/10.2147/AMEP.S146670

19. Gonzalo JD, Haidet P, Blatt B, Wolpaw DR. 2016. Exploring challenges in implementing a health systems science curriculum: a qualitative analysis of student perceptions. Med Educ. 50(5), 523-31. PubMed https://doi.org/10.1111/medu.12957

20. Li S, Bamidis PD, Konstantinidis ST, Traver V, Car J, et al. 2019. Setting priorities for EU healthcare workforce IT skills competence improvement. Health Informatics J. 25(1), 17485. PubMed https://doi.org/10.1177/1460458217704257

21. Fridsma DB. 2017. Developing the health informatics workforce of the future: academic and industry partners. J Am Med Inform Assoc. 24(3), 677-78. PubMed https://doi.org/10.1093/jamia/ocx027

22. LaVenture M, Brand B, Baker EL. 2017. Developing an Informatics-Savvy Health Department: From Discrete Projects to a Coordinating Program Part II: Creating a Skilled Workforce. J Public Health Manag Pract. 23(6), 638-40. PubMed https://doi.org/10.1097/PHH.0000000000000658

23. Gibson PJ, Shah GH, Streichert LC, Verchick L. Urgent Challenges for Local Public Health Informatics. J Public Health Manag Pract. 2016 Nov-Dec; 22 Suppl 6, Public Health Informatics (Suppl 6):S6-S8.

24. Kharrazi H, Lasser EC, Yasnoff WA, Loonsk J, Advani A, et al. 2017. A proposed national research and development agenda for population health informatics: summary recommendations from a national expert workshop. J Am Med Inform Assoc. 24(1), 2-12. Epub Mar 2016. doi:https://doi.org/10.1093/jamia/ocv210. PubMed

25. Whetton S, Hazlitt C. 2015. Educating the Health Informatics Professional: The Impact of an Academic Program. Stud Health Technol Inform. 214, 159-66. PubMed

26. Polner E. The 10 Best Job Search Websites of 2020 [Internet]. The Balance Careers. 2020 [cited 2020Sep10]. Available from: https://www.thebalancecareers.com/top-best-jobwebsites-2064080

27. Elo S, Kyngäs H. 2008. The qualitative content analysis process. J Adv Nurs. 62(1), 107-15. PubMed https://doi.org/10.1111/j.1365-2648.2007.04569.x

28. Meyer MA. 2019. Healthcare data scientist qualifications, skills, and job focus: a content analysis of job postings. J Am Med Inform Assoc. 26(5), 383-91. PubMed https://doi.org/10.1093/jamia/ocy181

29. Council on Education for Public Health. Accreditation Criteria Schools of Public Health \& Public Health Programs. Silver Spring, MD: Council on Education for Public Health (2016). 
30. Gamache R, Kharrazi H, Weiner JP. 2018. Public and Population Health Informatics: The Bridging of Big Data to Benefit Communities. Yearb Med Inform. 27(1), 199-206. PubMed https://doi.org/10.1055/s-0038-1667081

31. US Department of Health and Human Services (HHS) and Centers for Disease Control and Prevention. (CDC) and University of Washington School of Public Health and Community Medicine's Center for Public Health Informatics. Competencies for Public Health Informaticians 2009. Atlanta: U.S. Department of Health and Human Services, Centers for Disease Control and Prevention; (2009)

32. Kampov-Polevoi J, Hemminger BM. 2011. A curricula-based comparison of biomedical and health informatics programs in the USA. J Am Med Inform Assoc. 18(2), 195-202. PubMed https://doi.org/10.1136/jamia.2010.004259

33. Wholey DR, LaVenture M, Rajamani S, Kreiger R, Hedberg C, et al. 2018. Developing Workforce Capacity in Public Health Informatics: Core Competencies and Curriculum Design. Front Public Health. 6, 124. PubMed https://doi.org/10.3389/fpubh.2018.00124

34. Hsu CE, Dunn K, Juo HH, Danko R, Johnson D, et al. 2012. Understanding public health informatics competencies for mid-tier public health practitioners - a web-based survey. Health Informatics J. 18(1), 66-76. PubMed https://doi.org/10.1177/1460458211424000

35. Sapci AH, Sapci HA. 2020. Teaching Hands-On Informatics Skills to Future Health Informaticians: A Competency Framework Proposal and Analysis of Health Care Informatics Curricula. JMIR Med Inform. 8(1), e15748. PubMed https://doi.org/10.2196/15748 